\title{
EVALUATION OF NITROGEN APPLICATION METHODS AND RATES WITH NUTRISPHERE-N ON CORN IN SOUTHEASTERN COASTAL PLAINS
}

\author{
Pawel Wiatrak \\ School of Agricultural, Forest and Environmental Sciences, Clemson University, Edisto REC, Blackville, USA
}

Received 2013-11-16; Revised 2013-12-31; Accepted 2014-01-04

\begin{abstract}
Application method of Nitrogen $(\mathrm{N})$ and Nutrisphere-N may influence corn (Zea mays L.) growth and yields under dryland conditions. The objective of this study was to determine the effect of two $\mathrm{N}$ application methods (all at planting and split application with $35 \mathrm{~kg} \mathrm{~N} \mathrm{ha}^{-1}$ applied at planting and remaining $\mathrm{N}$ at V6 stage) and five $\mathrm{N}$ rates $\left(0,45,90,135\right.$ and $\left.180 \mathrm{~kg} \mathrm{~N} \mathrm{ha}^{-1}\right)$ with and without Nutrisphere- $\mathrm{N}$ polymer on dryland corn near Blackville, SC from 2010 to 2012. Compared to control, Nutrisphere-N polymer improved corn grain yield by 33.3 and $29.5 \%$ at 90 and $135 \mathrm{~kg} \mathrm{~N} \mathrm{ha}^{-1}$ applied at planting and 12.1, 12.9, 22.0 and $31.2 \%$ at $45,90,135$ and $180 \mathrm{~kg} \mathrm{~N} \mathrm{ha}^{-1}$ applied in split applications, respectively. Chlorophyll improved in corn leaves by $19.3 \%$ at 8 weeks after planting with application of $45 \mathrm{~kg} \mathrm{~N}^{-1}$ and Nutrisphere-N at planting. Split $\mathrm{N}$ application with Nutrisphere-N slightly improved chlorophyll in corn leaves. Nutrisphere-N increased plant LAI at 8 weeks after planting by $10.2 \%$ at $135 \mathrm{~kg} \mathrm{~N} \mathrm{ha}^{-1}$ in split applications and LAI at 16 weeks after planting by 50.4, 56.2, 59.4 and 70.7\% at 45, 90, 135 and $180 \mathrm{~kg} \mathrm{~N}$ $\mathrm{ha}^{-1}$ with split applications, respectively. Plant NDVI at 16 weeks after planting corn improved with Nutrisphere- $\mathrm{N}$ by $9.3,11.5,13.0$ and $9.2 \%$ with $\mathrm{N}$ applied at planting and $16.0,12.9,10.2$ and $14.3 \%$ with split $\mathrm{N}$ applications at $45,90,135$ and $180 \mathrm{~kg} \mathrm{ha}^{-1}$, respectively. Nutrisphere- $\mathrm{N}$ increased grain $\mathrm{N}$ by $4.5 \%$ at $135 \mathrm{~kg} \mathrm{~N} \mathrm{ha}^{-1}$ applied to corn at planting and $5.2 \%$ at $90 \mathrm{~kg} \mathrm{~N} \mathrm{ha}^{-1}$ applied in split applications. Generally, $\mathrm{N}$ applications with Nutrisphere-N positively improved growth parameters and yields of corn.
\end{abstract}

Keywords: Corn, Nutrisphere-N, Normalized Difference Vegetation Index (NDVI), Leaf Area Index (LAI), Polymer

\section{INTRODUCTION}

More fertilizers are required to support World population, but may contribute to environmental pollution unless important issues are sufficiently addressed (Ni et al., 2011). Cahill et al. (2010) pointed out that due to increasing fertilizer prices growers are looking for ways to decrease $\mathrm{N}$ input in crop production. Due to increasing awareness of natural resources sustainability, there are efforts to develop environmentally friendly $\mathrm{N}$ application methods to improve sustainability of crop production (Shaviv, 2005). This can be accomplished by synchronizing plant demands with supplying sufficient $\mathrm{N}$.
Nitrification and ammonia volatility may lead to contamination of $\mathrm{N}$ in the soil surface and underground water (Hubbard et al., 2004) and these are very important aspects in improving crop $\mathrm{N}$ uptake and use efficiency in crops (Franzen et al., 2011). Hubbard et al. (2004) mentioned that $\mathrm{NO}_{3}-\mathrm{N}$ and $\mathrm{NO}_{2}-\mathrm{N}$ movement into groundwater is a problem in the southeastern Coastal Plain due to warm temperatures and relatively high rainfall. Optimum irrigation and $\mathrm{N}$ fertilization can help to reduce nitrate leaching and improve $\mathrm{N}$ uptake and crop yield (Martinez-Alcantara et al., 2012).

Some concepts in improving $\mathrm{N}$ management include splitting $\mathrm{N}$ application, nitrification and urease inhibitors and using slow release fertilizers (Shaviv, 2005), which can 
decrease volatilization and improve yields (Cahill et al., 2010). Ni et al. (2009) indicated that slow-release urea coated fertilizer can help to reduce environmental pollution. In their study, ethylcellulose and poly (acrylic acid-co-acrylamide) were utilized as coating products, which helped to reduce $\mathrm{N}$ loss and improve water use efficiency. Another product, urea coated with Nutrisphere-N has both nitrification and urea volatilization inhibiting properties (Franzen et al., 2011).

Current methods to determine optimum $\mathrm{N}$ rates for corn need to evaluate factors influencing $\mathrm{N}$ uptake (Kyveryga et al., 2013) and quantify supplied and immobilized nutrients in the soil, especially for the site specific nutrient management (Anthony et al., 2012). Cahill et al. (2010) pointed out that growers need to evaluate location and climate to decide about using alternative products. Therefore, objective of this study was to evaluate the effect of $\mathrm{N}$ application methods and rates with Nutrisphere-N polymer on dryland corn in Southeastern Coastal Plains.

\section{MATERIALS AND METHODS}

\subsection{Site Preparation and Management}

This study was conducted on Dothan loamy sand (fine loamy, kaolinitic, thermic Plinthic Kandiudult) at Clemson University, Edisto Research and Education Center (REC) near Blackville, SC (33 21' N, 81 $19^{\prime} \mathrm{W}$ ) under dryland conditions from 2010 to 2012 . These are deep, well drained soils with slow permeability and soil $\mathrm{pH}$ was 6.2. Wheat cover crop was planted in November/December of 2009, 2010 and 2011 and was killed in early March of the following year. Corn cv. 'Pioneer 31G71' was planted following wheat cover crop at 69,200 seeds ha $^{-1}$ in strip-till using a Univerferth Ripper-Stripper (Unverferth Mtg. Co., Inc., Falida, OH) implement and John Deere 1700 MaxEmerge XP Vaccum planters (John Deere Co., Moline, IL) on 25, 18 and 14 March in 2010, 2011 and 2012, respectively. The plot size was $6.1 \mathrm{~m}$ long by $3.9 \mathrm{~m}$ wide with four corn rows and $0.96 \mathrm{~m}$ row spacing.

Nitrogen treatments consisted of two $\mathrm{N}$ application methods (all at once at planting and as a split application with $35 \mathrm{~kg} \mathrm{~N} \mathrm{ha}^{-1}$ applied at planting and the rest as a side-dress application at V6 corn stage) and five nitrogen rates $\left(0,45,90,135\right.$ and $\left.180 \mathrm{~kg} \mathrm{~N} \mathrm{ha}^{-1}\right)$.

Liquid fertilizer 25-S (liquid formulation of $25 \% \mathrm{~N}$ and $3.5 \% \mathrm{~S}$ ) was applied on both sides of corn rows to selected plots using a Reddick fertilizer applicator (Reddick Equipment Co., Inc., Williamson, NC) following corn planting. Corn in selected plots was sidedressed with different nitrogen rates at V6 stage using a Reddick fertilizer applicator on 14 May 2010 and 9 May in 2011 and 2012. Weed control was based on the South Carolina Extension recommendations.

\subsection{Plant Measurements}

Plant measurements were conducted in the center of each plot. Chlorophyll was measured in corn leaves using Minolta SPAD-502 chlorophyll meter (Minolta Camera Co. Ltd., Japan). Normalized Difference Vegetation Index (NDVI) was measured using handheld GreenSeeker ${ }^{\mathrm{TM}}$ (NTech Industries, Inc. Ukiah, CA) instrument and the Leaf Area Index (LAI) LAI-2000 (Li-Cor, Lincoln, NE) meter was used to measure plant index.

Corn was harvested using either Almaco (Nevada, Iowa) or Kinkaid 8XP (Kinkaid Equip. Mtg, Haven, Kansas) small grain plot combine on 27,8 and 4 August in 2010, 2011 and 2012, respectively. Grain Samples from all harvested plots were evaluated for weight and moisture content using a Burrows Model 750 Digital Moisture Computer (Seedburo Equip. Co., Chicago, IL). Corn grain yields were corrected to 155 $\mathrm{g} \mathrm{kg}^{-1}$ moisture content. Additionally, weather data (air temperature and precipitation) were recorded during soybean vegetation using a weather station located near the experimental site.

\subsection{Statistical Analysis}

The study design was a Randomized Complete Block with four replications. Data were analyzed using the general linear models in SAS (2011) and means with standard error bars were shown for $\mathrm{N}$ rates by $\mathrm{N}$ application method.

\section{RESULTS}

\subsection{Weather Conditions}

Monthly average temperature, precipitation and average from the 30-year average are shown in Table $\mathbf{1 .}$ The average monthly air temperature was generally similar to 30-year average, except for March 2012, April 2011, May 2010 and 2012, June 2010 and 2011, July 2011 and August 2012 when temperature was 3.5, 1.3, $1.8,1.3,2.3,2.3,1.3$ and $1.1^{\circ} \mathrm{C}$ higher and March 2012 and June 2012 when temperature was 2.8 and $1.4^{\circ} \mathrm{C}$ lower than 30-year average, respectively. 
Pawel Wiatrak / American Journal of Agricultural and Biological Sciences 9 (1): 109-118, 2014

Table 1. Monthly average air temperature and precipitation during soybean growth near Blackville, SC from 2010 to 2012

\begin{tabular}{|c|c|c|c|c|c|c|c|}
\hline \multirow[b]{2}{*}{ Year } & \multicolumn{7}{|c|}{ Month } \\
\hline & Mar. & Apr. & May & June & July & Aug. & Average/Total \\
\hline \multicolumn{8}{|c|}{ Temperature $\left({ }^{\circ} \mathbf{C}\right)$} \\
\hline 2010 & 11.3 & 18.2 & 23.7 & 27.5 & 27.6 & 16.9 & 20.9 \\
\hline 2011 & 13.4 & 19.1 & 22.3 & 27.4 & 28.0 & 18.0 & 21.4 \\
\hline 2012 & 17.6 & 18.5 & 23.2 & 23.8 & 27.7 & 18.8 & 21.6 \\
\hline 30-year avg. & 14.1 & 17.8 & 21.8 & 25.2 & 26.8 & 17.8 & 20.6 \\
\hline \multicolumn{8}{|c|}{ Precipitation (mm) } \\
\hline 2010 & 64.0 & 25.0 & 88.0 & 187.0 & 103.0 & 162.0 & 629.0 \\
\hline 2011 & 123.0 & 57.0 & 59.0 & 58.0 & 140.0 & 182.0 & 619.0 \\
\hline 2012 & 119.0 & 44.0 & 173.0 & 80.0 & 97.0 & 309.0 & 822.0 \\
\hline 30-year avg. & 105.0 & 80.0 & 87.0 & 129.0 & 130.0 & 122.0 & 653.0 \\
\hline
\end{tabular}

Precipitation was $169 \mathrm{~mm}$ greater during corn growing season in 2012 and 24 and $34 \mathrm{~mm}$ lower in 2010 and 2011 than 30-year average, respectively (Table 1). Insufficient precipitation was recorded in March and July 2010, April in all 3 years, May 2011, June 2011 and 2012 and July in 2010 and 2012. Higher than 30-year precipitation was recorded in March 2011 and 2012, May 2012, June 2010, July 2012 and August for all 3 years.

\subsection{Chlorophyll, Plant Leaf Area Index (LAI) and Normalized Difference Vegetation Index (NDVI)}

Nitrogen application with Nutrisphere-N improved chlorophyll in plant leaves by $19.3 \%$ at $45 \mathrm{~kg} \mathrm{~N} \mathrm{ha}^{-1}$ applied at planting compared to untreated $\mathrm{N}$ application at 8 weeks after corn planting (Fig. 1). Chlorophyll content was similar for treatments with higher $\mathrm{N}$ rates applied at planting with and without polymer. Nitrogen applied to corn in split applications slightly improved chlorophyll content, especially at higher $\mathrm{N}$ application rates (Fig. 2).

Plant LAI was either similar or greater from $\mathrm{N}$ treatments with Nutrisphere-N applications at 8 and 16 weeks after corn planting (Fig. 3-6). Addition of Nutrisphere- $\mathrm{N}$ to $135 \mathrm{~kg} \mathrm{~N}^{-1}$ in split applications improved plant LAI by $10.2 \%$ at 8 weeks after planting. Similar or slightly higher LAI values were observed with Nutrisphere-N polymer for other $\mathrm{N}$ application rates. Measurements at 16 weeks after planting indicated 50.4, 56.2, 59.4 and $70.7 \%$ greater LAI with Nutrisphere-N polymer application than without polymer at $45 \mathrm{~kg}, 90 \mathrm{~kg}, 135 \mathrm{~kg}$ and $180 \mathrm{~kg} \mathrm{~N}$ $\mathrm{ha}^{-1}$ applied to corn in split applications, respectively. Plant LAI at 8 and 16 weeks after planting corn was similar for treatments with $\mathrm{N}$ applied at planting with and without Nutrisphere-N.

Plant NDVI at 16 weeks after planting was 9.3, 11.5, 13.0 and $9.2 \%$ greater with Nutrisphere-N polymer for $\mathrm{N}$ applied at planting and 16.0, 12.9, 10.2 and $14.3 \%$ greater with polymer over untreated $\mathrm{N}$ at $45 \mathrm{~kg}, 90 \mathrm{~kg}$, $135 \mathrm{~kg}$ and $180 \mathrm{~kg} \mathrm{~N} \mathrm{ha}{ }^{-1}$ in split applications, respectively (Fig. 7 and 8 ).

\subsection{Ear-leaf N, Grain Yield and Grain N Content}

Corn ear-leaf $\mathrm{N}$ concentration at R1 stage was either similar or slightly higher for $\mathrm{N}$ treatments with Nutrisphere-N polymer (Fig. 9 and 10).

Generally, greater corn yields were obtained from $\mathrm{N}$ treatments with Nutrisphere- $\mathrm{N}$ application than without polymer (Fig. 11 and 12). With all $\mathrm{N}$ applied at planting, corn grain yield increased by 33.3 and $29.5 \%$ with application of Nutrisphere-N polymer at $90 \mathrm{~kg}$ and $135 \mathrm{~kg} \mathrm{~N}^{-1}$ compared to untreated N. For split $\mathrm{N}$ applications, Nutrisphere-N polymer improved corn yields by $12.1,12.9,22.0$ and $31.2 \%$ over untreated $\mathrm{N}$.

Grain N concentration was $4.5 \%$ greater at $135 \mathrm{~kg}$ $\mathrm{N} \mathrm{ha}^{-1}$ and Nutrisphere-N polymer applied at planting and $5.2 \%$ greater at $90 \mathrm{~kg} \mathrm{~N}^{-1}$ applied with polymer to corn in split applications (Fig. 13 and 14). Grain $\mathrm{N}$ concentrations were similar for treatments with and without Nutrisphere- $\mathrm{N}$ for other $\mathrm{N}$ application rates. 
Pawel Wiatrak / American Journal of Agricultural and Biological Sciences 9 (1): 109-118, 2014

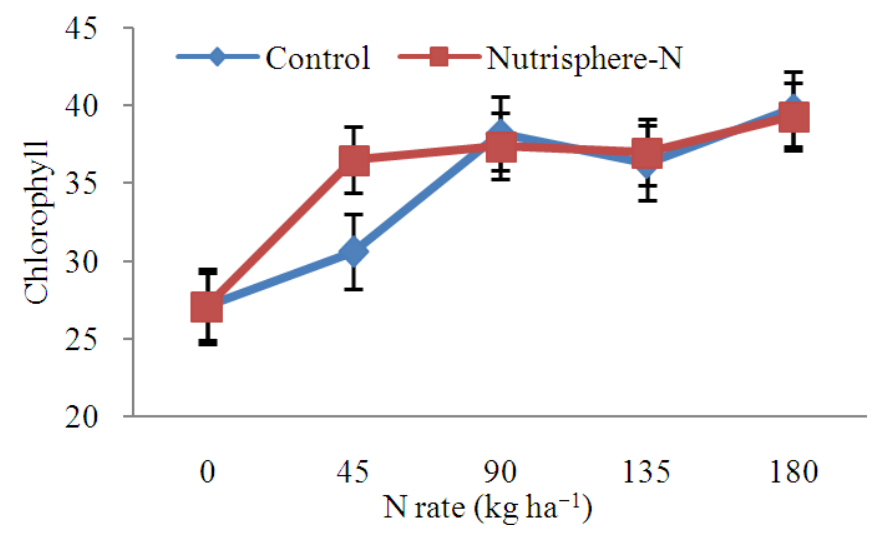

Fig. 1. Influence of $\mathrm{N}$ application rate at planting with Nutrisphere- $\mathrm{N}$ on chlorophyll content in corn leaves at 8 weeks after planting corn. Vertical bars indicate standard error

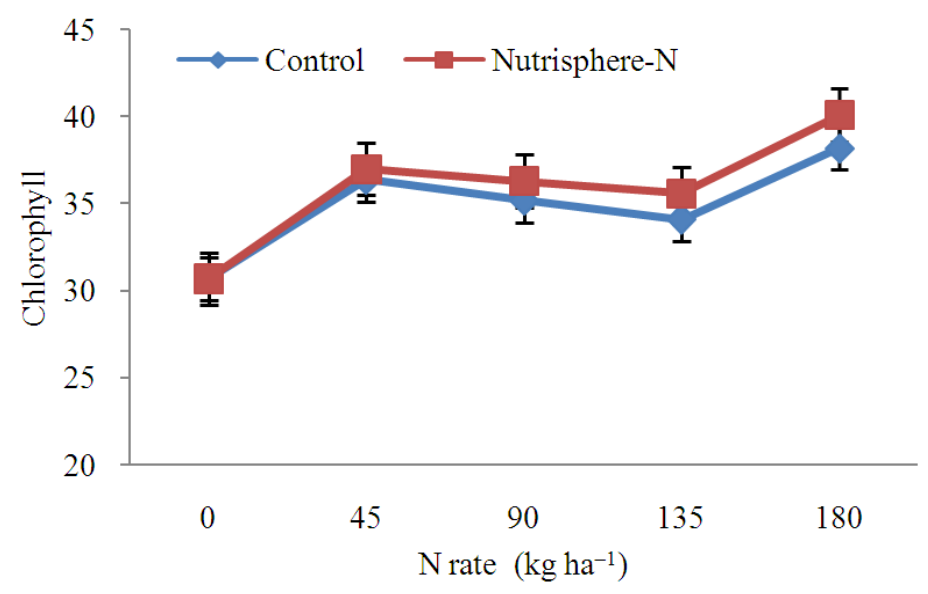

Fig. 2. Influence of split $\mathrm{N}$ application rate with Nutrisphere- $\mathrm{N}$ on chlorophyll content in corn leaves at 8 weeks after planting corn. Vertical bars indicate standard error

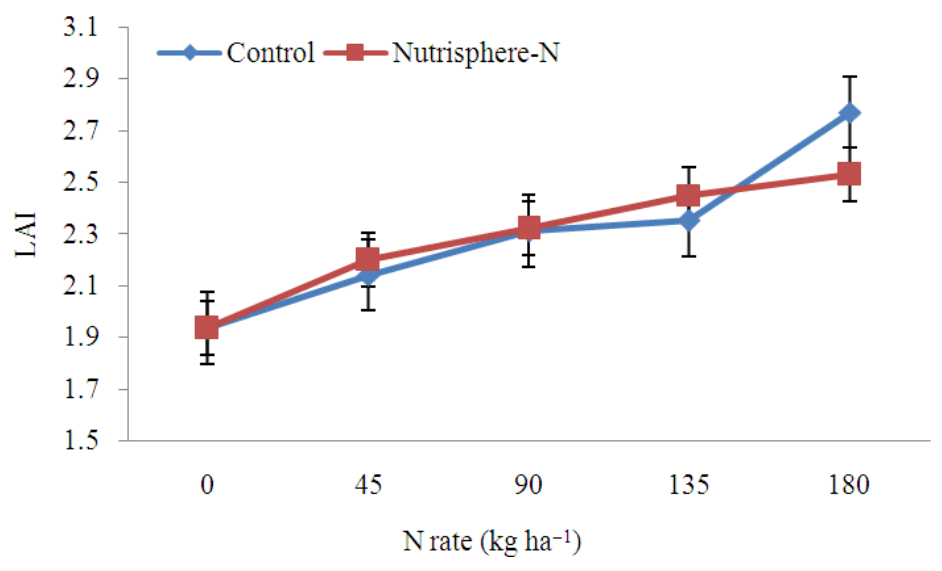

Fig. 3. Influence of $\mathrm{N}$ application rate at planting with Nutrisphere- $\mathrm{N}$ on corn Leaf Area Index (LAI) at 8 weeks after planting corn. Vertical bars indicate standard error 


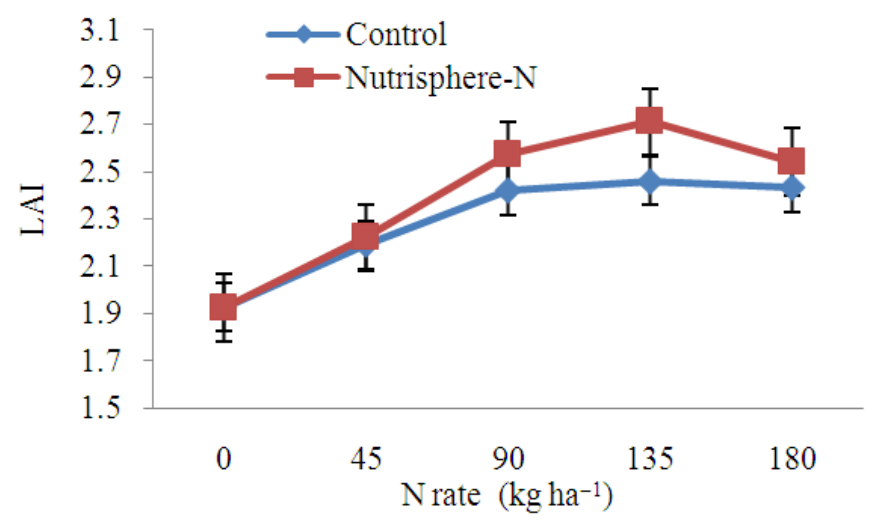

Fig. 4. Influence of split $\mathrm{N}$ application rate at planting with Nutrisphere-N on corn Leaf Area Index (LAI) at 8 weeks after planting corn. Vertical bars indicate standard error

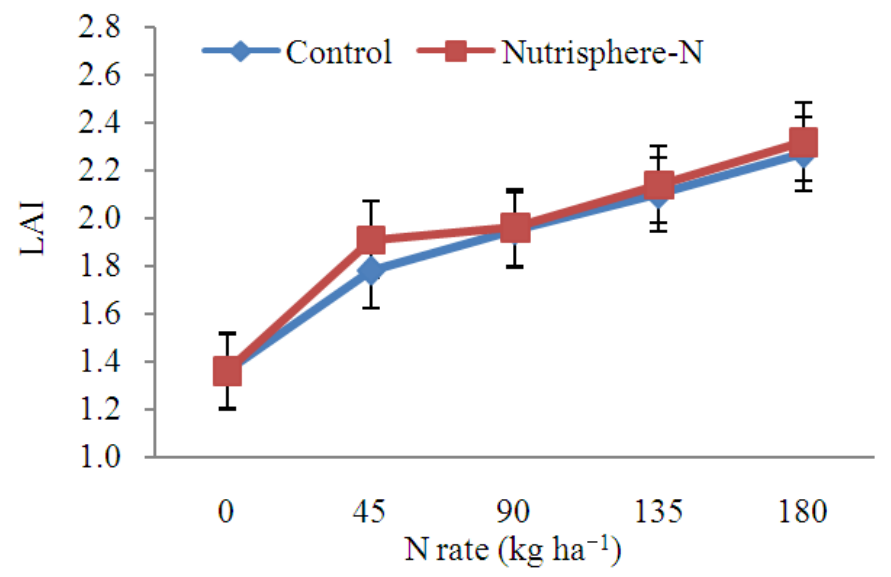

Fig. 5. Influence of $\mathrm{N}$ application rate at planting with Nutrisphere-N on corn Leaf Area Index (LAI) at 16 weeks after planting corn. Vertical bars indicate standard error

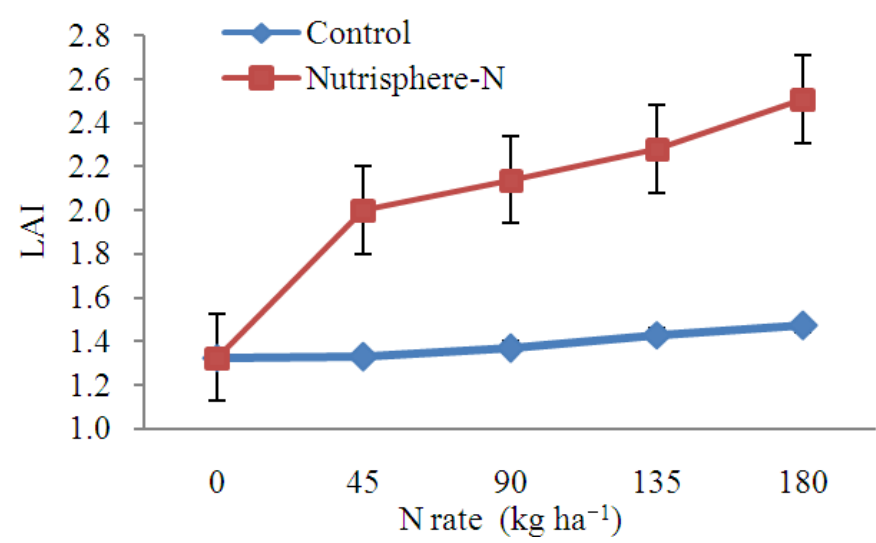

Fig. 6. Influence of split $\mathrm{N}$ application rate at planting with Nutrisphere-N on corn Leaf Area Index (LAI) at 16 weeks after planting corn. Vertical bars indicate standard error 


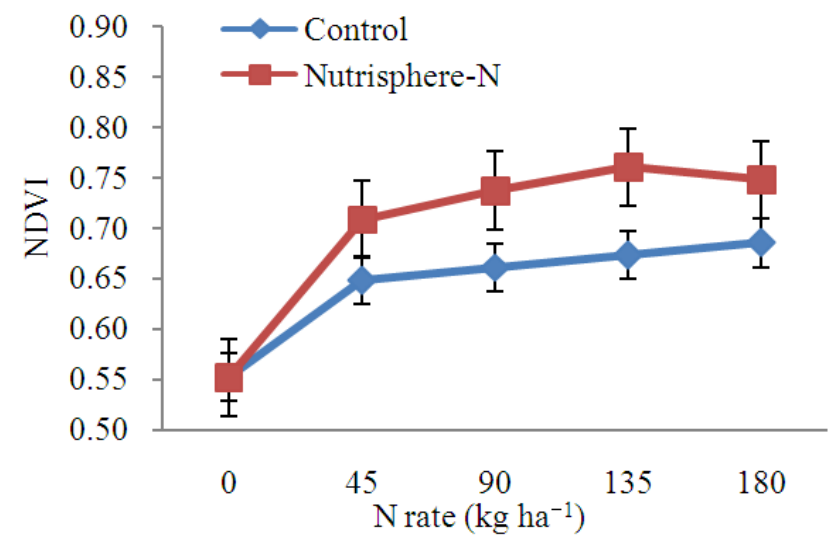

Fig. 7. Influence of $\mathrm{N}$ application rate at planting with Nutrisphere-N on corn Normalized Difference Vegetation Index (NDVI) at 16 weeks after planting corn. Vertical bars indicate standard error

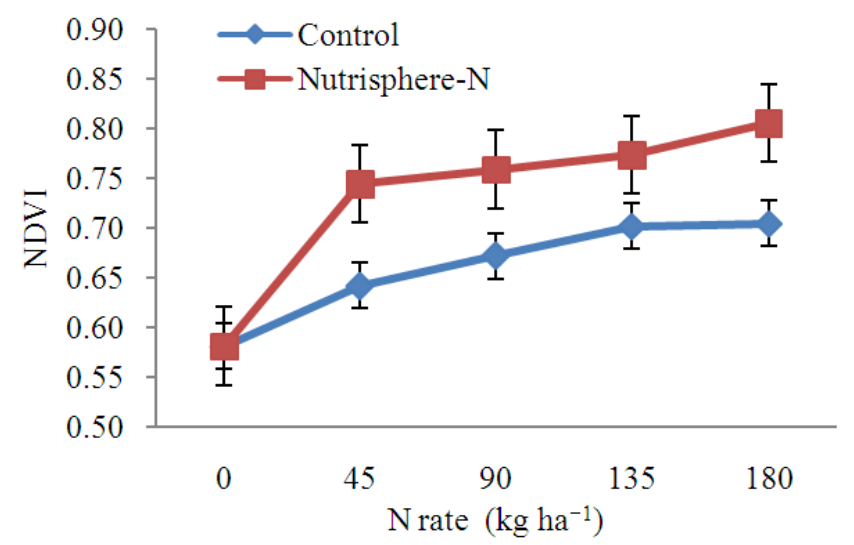

Fig. 8. Influence of split $\mathrm{N}$ application rate at planting with Nutrisphere-N on corn Normalized Difference Vegetation Index (NDVI) at 16 weeks after planting corn. Vertical bars indicate standard error

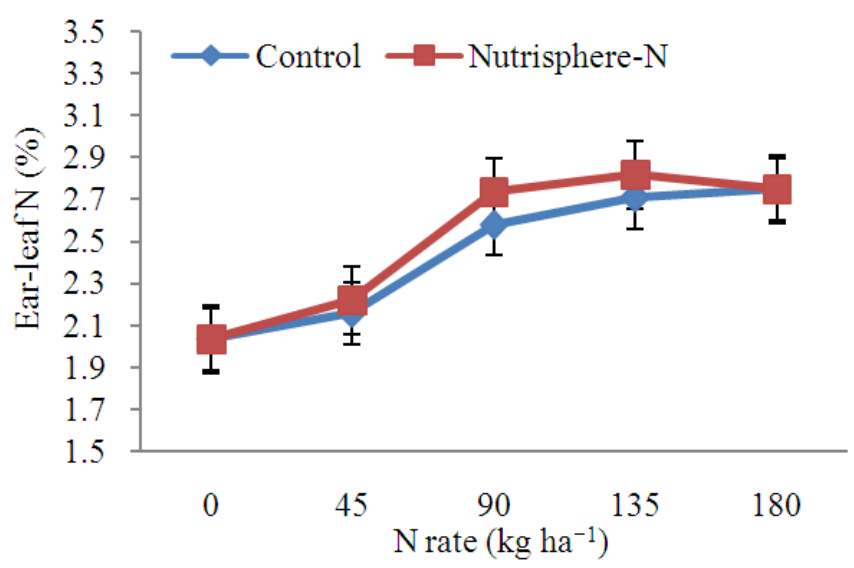

Fig. 9. Influence of $\mathrm{N}$ application rate at planting with Nutrisphere- $\mathrm{N}$ on $\mathrm{N}$ concentration in corn leaves at $\mathrm{R} 1$ stage. Vertical bars indicate standard error 


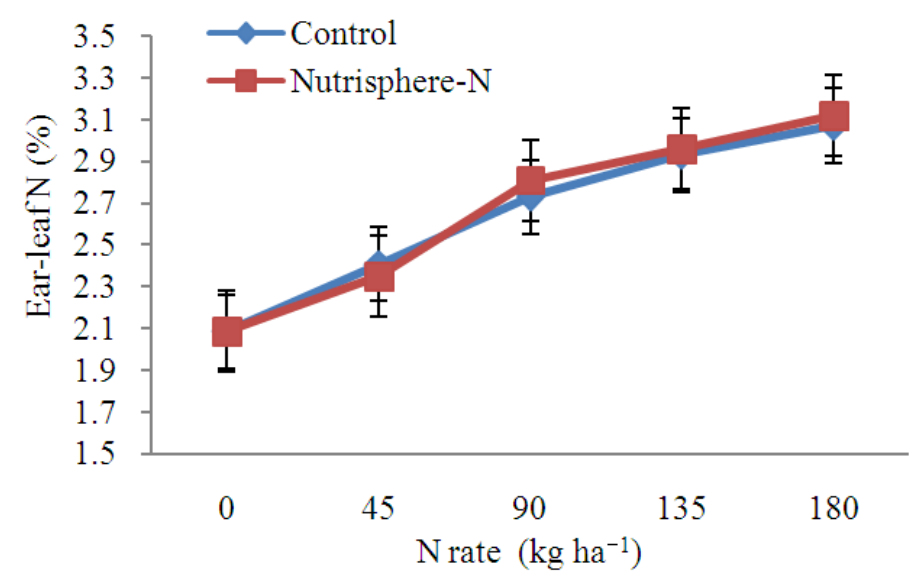

Fig. 10. Influence of split $\mathrm{N}$ application rate at planting with Nutrisphere- $\mathrm{N}$ on $\mathrm{N}$ concentration in corn leaves at $\mathrm{R} 1$ stage. Vertical bars indicate standard error

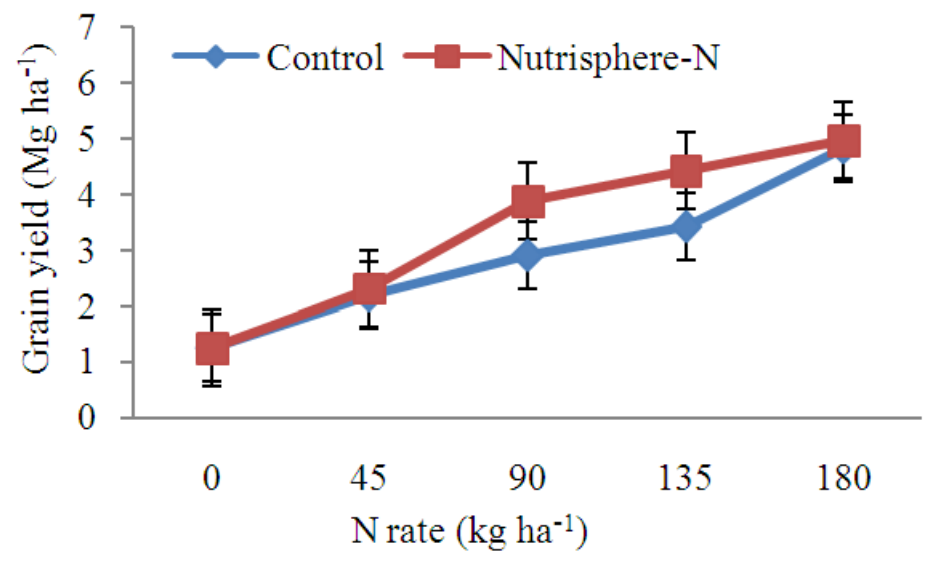

Fig. 11. Influence of $\mathrm{N}$ application rate at planting with Nutrisphere- $\mathrm{N}$ on corn grain yields. Vertical bars indicate standard error

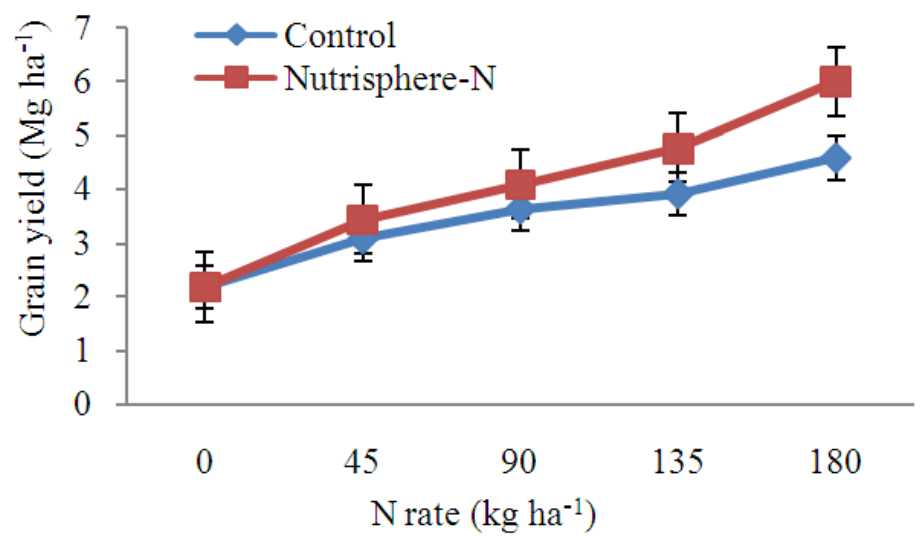

Fig. 12. Influence of split $\mathrm{N}$ application rate at planting with Nutrisphere-N on corn grain yields. Vertical bars indicate standard error 


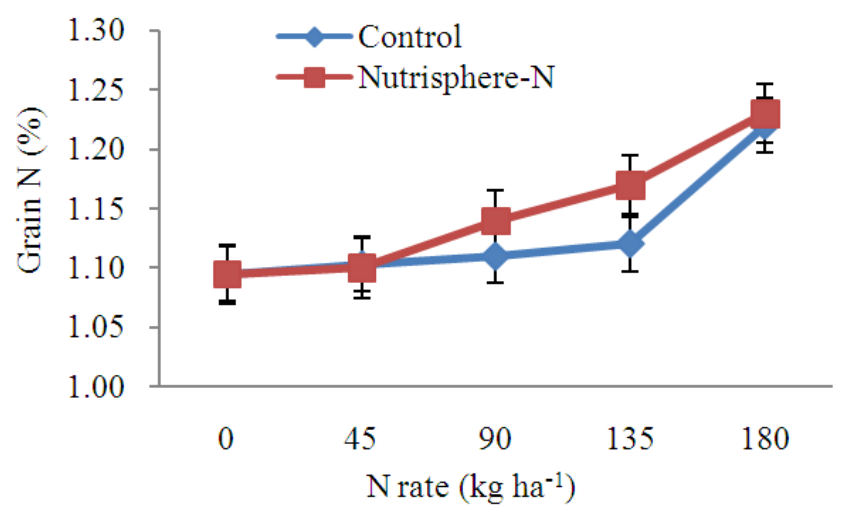

Fig. 13. Influence of $\mathrm{N}$ application rate at planting with Nutrisphere- $\mathrm{N}$ on $\mathrm{N}$ concentration in corn grain. Vertical bars indicate standard error

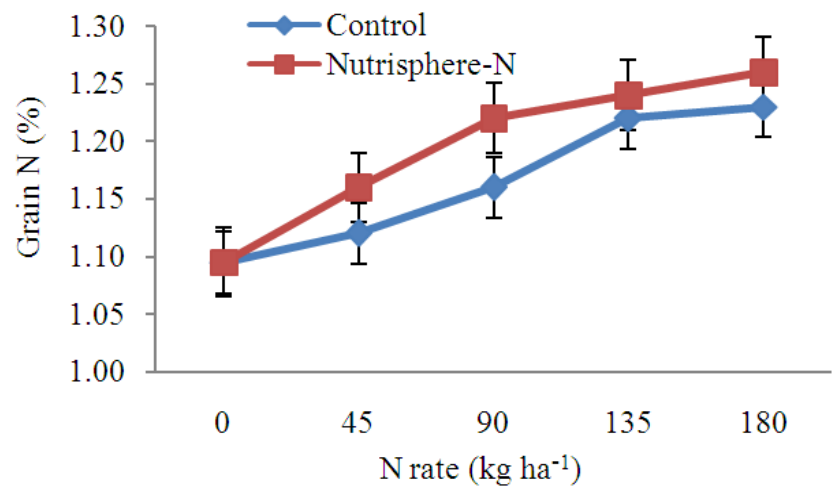

Fig. 14. Influence of split $\mathrm{N}$ application rate at planting with Nutrisphere- $\mathrm{N}$ on $\mathrm{N}$ concentration in corn grain. Vertical bars indicate standard error

\section{DISCUSSION}

Previous research was not conclusive. Slow-release N products did not always significantly improve crop yields (Stagnari and Pisante, 2012). Man et al. (2011) did not observe a significant difference in plant dry matter and grain yields of winter wheat (Triticum aestivum L.) between coated urea and uncoated urea. Franzen et al. (2011) noted that spring wheat and rice did not produce higher yields with Nutrisphere-N compared to urea.

However, Cahill et al. (2010) indicated that Nutrisphere-N improved yields of corn stover. Alternative products were not consistent in increasing corn or wheat grain yields compared to conventional fertilizer, but Nutrisphere-N increased yield of wheat straw in three out of four site years (Cahill et al., 2010). Madani et al. (2012) reported that biomass and straw yield of drought-stressed wheat improved with increased $\mathrm{N}$ application rates.
This study showed that Nutrisphere-N improved chlorophyll in plant leaves by $19.3 \%$ at 8 weeks after corn planting with $45 \mathrm{~kg} \mathrm{~N}^{-1}$ applied at planting. Split $\mathrm{N}$ application slightly improved chlorophyll content. Application of $135 \mathrm{~kg} \mathrm{~N} \mathrm{ha}^{-1}$ with Nutrisphere-N in split applications improved plant LAI by $10.2 \%$ at 8 weeks after planting. Plant LAI at 16 weeks after planting was $50.4,56.2,59.4$ and $70.7 \%$ greater at $45 \mathrm{~kg}, 90 \mathrm{~kg}, 135$ $\mathrm{kg}$ and $180 \mathrm{~kg} \mathrm{ha}^{-1} \mathrm{~N}$ applied with Nutrisphere-N in split applications, respectively. Plant NDVI at 16 weeks after planting was 9.3, 11.5, 13.0 and $9.2 \%$ greater for $\mathrm{N}$ applied at planting and 16.0, 12.9, 10.2 and $14.3 \%$ higher at $45 \mathrm{~kg}, 90 \mathrm{~kg}, 135 \mathrm{~kg}$ and $180 \mathrm{~kg} \mathrm{~N} \mathrm{ha}^{-1}$ applied in split applications with Nutrisphere-N, respectively. Corn grain yield increased by $33.3 \%$ and $29.5 \%$ at $90 \mathrm{~kg}$ and $135 \mathrm{~kg} \mathrm{~N} \mathrm{ha}{ }^{-1}$ applied at planting with Nutrisphere-N, respectively. Additionally, application of $45 \mathrm{~kg}, 90 \mathrm{~kg}, 135 \mathrm{~kg}$ and $180 \mathrm{~kg} \mathrm{~N}^{-1}$ in split applications with Nutrisphere-N increased corn yields 
by $12.1,12.9,22.0$ and $31.2 \%$, respectively. Grain $\mathrm{N}$ improved by $4.5 \%$ at $135 \mathrm{~kg} \mathrm{~N}$ applied with Nutrisphere- $\mathrm{N}$ at planting and $5.2 \%$ at $90 \mathrm{~kg} \mathrm{~N} \mathrm{ha}^{-1}$ applied with Nutriplant-N in split applications.

\section{CONCLUSION}

This study investigated the effect of two $\mathrm{N}$ application methods and five $\mathrm{N}$ application rates with Nutrisphere-N polymer on growth and yield of corn grown under dryland conditions. Compared to untreated $\mathrm{N}$, application of $45 \mathrm{~kg} \mathrm{~N} \mathrm{ha}{ }^{-1}$ with Nutrisphere-N polymer at planting improved chlorophyll in plant leaves by $19.3 \%$. Higher $\mathrm{N}$ rates produced similar chlorophyll content in plant tissues for treatments with and without polymer. Split N applications with Nutrisphere-N slightly improved chlorophyll content, especially at higher $\mathrm{N}$ application rates.

Plant LAI at 8 weeks after planting increased by $10.2 \%$ at $135 \mathrm{~kg} \mathrm{~N} \mathrm{ha}^{-1}$ with Nutrisphere- $\mathrm{N}$ polymer applied in split applications over untreated N. Adding Nutrisphere-N polymer generally did not affect plant LAI for other $\mathrm{N}$ rates. Plant LAI at 16 weeks after planting was 50.4, 56.2, 59.4 and $70.7 \%$ greater with Nutrisphere-N polymer at $45,90,135$ and $180 \mathrm{~kg} \mathrm{ha}^{-1} \mathrm{~N}$ with split applications, respectively. Similar LAI was observed for $\mathrm{N}$ applied at planting with and without Nutrisphere-N at 8 and 16 weeks after planting corn.

Application of Nutrisphere-N polymer improved plant NDVI by $9.3,11.5,13.0$ and $9.2 \%$ for $\mathrm{N}$ treatments applied at planting and 16.0, 12.9, 10.2 and $14.3 \%$ for split $\mathrm{N}$ applications at $45,90,135$ and $180 \mathrm{~kg} \mathrm{~N} \mathrm{ha}^{-1}$ at 16 weeks after planting, respectively. The corn ear-leaf $\mathrm{N}$ concentration at $\mathrm{R} 1$ stage was similar for treatments with Nutrisphere-N and untreated fertilizer.

Compared to untreated control, addition of Nutrisphere-N polymer improved corn grain yield by 33.3 and $29.5 \%$ at $90 \mathrm{~kg}$ and $135 \mathrm{~kg} \mathrm{~N} \mathrm{ha}^{-1}$ applied at planting, respectively. For split $\mathrm{N}$ applications, corn grain yields increased by $12.1,12.9,22.0$ and $31.2 \%$ at $45,90,135$ and $180 \mathrm{~kg} \mathrm{~N} \mathrm{ha}^{-1}$ with Nutrisphere-N than untreated N. Nutrisphere-N polymer improved grain $\mathrm{N}$ concentration by $4.5 \%$ at $135 \mathrm{~kg} \mathrm{~N} \mathrm{ha}^{-1}$ applied at planting and $90 \mathrm{~kg} \mathrm{~N} \mathrm{ha}^{-1}$ with split application. Smaller differences between $\mathrm{N}$ concentrations were observed for other $\mathrm{N}$ rates with and without Nutrisphere-N. Future research may evaluate Nutrisphere-N under different soil moisture conditions during corn growing season.

\section{ACKNOWLEDGEMENT}

I greatly appreciate a financial support from Specialty Fertilizer Products (SFP) for conducting field research.

\section{REFERENCES}

Anthony, P., G. Malzer, M.C. Zhang and S. Sparrow, 2012. Soil nitrogen and phosphorus behavior in a long-term fertilization experiment. Agron. J., 104: 1223-1237. DOI: 10.2134/agronj2012.0020

Cahill, S., D. Osmond, R. Weisz and R. Heiniger, 2010. Evaluation of alternative nitrogen fertilizers for corn and winter wheat production. Agron. J., 102: 12261236. DOI: 10.2134/agronj2010.0095

Franzen, D., R.J. Goos, R.J. Norman, T.W. Walker and T.L. Roberts et al., 2011. Field and laboratory studies comparing Nutrisphere-nitrogen urea with urea in North Dakota, Arkansas and Mississippi. J. Plant Nutr., 34: 1198-1222. DOI: 0.1080/01904167.2011.558162

Hubbard, R.K., J.M. Sheridan, R. Lowrance, D.D. Bosch and G. Vellidis, 2004. Fate of nitrogen from agriculture in the southeastern Coastal Plain. J. Soil Water Cons., 59: 72-86.

Kyveryga, P.M., P.C. Caragea, M.S. Kaiser and T.M. Blackmer, 2013. Predicting risk from reducing nitrogen fertilization using hierarchical models and on-farm data. Agron. J., 105: 85-94. DOI: 10.2134/agronj2012.0218

Madani, A., A.H. Makarem, F. Vazin and M. Joudi, 2012. The impact of post-anthesis nitrogen and water availability on yield formation of winter wheat. Plant Soil Environ., 58: 9-14.

Man, J.G., J. Zhou, D. Wang, Z.W. Yu, M. Zhang and Z.Y. Hu et al., 2011. Effects of sulfur plus resincoated controlled release urea fertilizer on winter wheat dry matter accumulation and allocation and grain yield. Ying Yong Sheng Tai Xue Bao., 22: 1175-1182. PMID: 21812291

Martinez-Alcantara, B., A. Quinones, M.A. FornerGiner, D.J. Iglesias and E. Primo-Millo et al., 2012. Impact of fertilizer-water management on nitrogen use efficiency and potential nitrate leaching in citrus trees. Soil Sci. Plant Nutr., 58: 659-669. DOI: 10.1080/00380768.2012.733678

Ni, B.L., M.Z. Liu and S.Y. Lu, 2009. Multifunctional slow-release urea fertilizer from ethylcellulose and superabsorbent coated formulations. Chem Eng. J., 155: 892-898. DOI: 10.1016/j.cej.2009.08.025 
Ni, B.L., M.Z. Liu, S.Y. Lu, L.H. Xie and Y.F. Wang, 2011. Environmentally friendly slow-release nitrogen fertilizer. J. Agric. Food Chem., 59: 1016910175. DOI: $10.1021 / \mathrm{jf} 202131 \mathrm{z}$

SAS, 2011. SAS/STAT® 9.3 User's Guide. SAS Institute Inc, Cary, NC.
Shaviv, A., 2005. Environmental friendly nitrogen fertilization. Sci. China Series C: Life Sci., 48: 937947. DOI: $10.1360 / 062005-285$

Stagnari, F. and M. Pisante, 2012. Slow release and conventional $\mathrm{N}$ fertilizers for nutrition of bell pepper. Plant Soil Environ., 58: 268-274. 